\title{
Interface Value:
}

\section{Market Mediatisation and the Logic of the Celebrity Brand}

\section{Douglas Brownlie (Dundee University), Paul Hewer (Strathclyde University) and Finola Kerrigan (Birmingham University)}

\begin{abstract}
"Killian held his impromptu press conference on the steps, he had died and been reborn. In his new incarnation, the press was no longer an enemy and it was no longer out there. The press was now a condition, like erythematosus or Wegener's granulomatosis. His entire central nervous system was now wired to the vast, incalculable circuits of radio and television and newspapers, and his body surged and burned and hummed with the energy of the press and the prurience of those it reached, which was everyone..." (Wolfe, 1988: 547)
\end{abstract}

It is almost 30 years since Tom Wolfe first 'celebrated' the sinful vanities of greed, class and racism lurking behind Wall Street successes of the 1980s. Since then the excess of city traders and bankers has hardly moderated; nor has the media lost its appetite for reproducing such excess as moralising narratives of avarice, corruption and claims of cynically manipulative practices informing neoliberal market capitalism. 
Beyond commentary on a culture of high-profile moral posturing set to sell anything and everything as media product, one detects two trenchant and defining insights born of nascent informational capitalism (Castells, 2001). The first relates to the immersion of identity in 'vast incalculable circuits' of connectivity; not merely of the conventional media of Wolfe's era, but of the vast global enterprise of networked society and its computer mediated worlds where, as predicted, selfdom is indeed experienced as being "multiple, fluid, and constituted in interaction with machine connections; it is [indeed] made and transformed by language; sexual congress is [indeed] an exchange of signifiers; and understanding [indeed] follows from navigation and tinkering rather than analysis "(Turkle, 1997: 15). The second relates to the ongoing explosion of new technologies of reproduction in that the identification of the commodity with its image as media content occurs under conditions governed by the "systematic production of messages, not from the world, but from the medium itself" (Baudrillard, 1998: 125); and that the interplay of connectivity as mediatised sociality animates symbolic circulation to the point where everyday interactivity consists in a 'mass medium at the level of the brand' (Baudrillard, ibid). These insights suggest Lury's (2004) exposition of the brand as an 'interface: a frame that organises and connects as a site of interactivity with its own recursive logic independent of context' (Lury: 51). Indeed, in writing that "the brand is an image instrument, a medium of translation, a new media object" Lury (ibid: 49) not only restates Douglas and Isherwood's (1980: 62) view that 
"the essential function of consumption is its capacity to make sense", to make meaning, to think with: she anticipates the underlying concern of this special issue that brands function as distributed cultural intermediaries; and that this is most apparent empirically at the level of the celebrity brand.

Jameson's (1991) analogy between media and market culture under conditions of informational capitalism and dematerialisation lies at the heart of this special issue. It sets in motion the idea of brands as media of exchange (Giddens, 1991); and celebrity brands as the mediatised embodiment of market logics which reach into cultural fields and shared experience spinning them as everyday capacities to produce a common, branded, social world of being (Hewer, Brownlie \& Kerrigan, 2013). That brands are tools to think with, to sculpt positions of identity through framing shared relations and experiences is also the discursive preamble of Arvidsson's (2006) luminous exposition of the brand under conditions of mediatised consumer culture. He observes that the "mediatisation of consumption created a commonly available informational environment that made resources that primarily had been private, the outcome of good breeding, or what Pierre Bourdieu (1984) called 'class habitat', public: generally available in the public domain" (ibid: 29). To consider the market environment as an information system in this sense is hardly a novel insight in marketing studies; but as the scope of mediatised consumer culture expands, reaching into many areas of everyday practice, it becomes less and less controversial to argue that media objects, 
symbolic tokens (Giddens, 1991) such as celebrity brands, "mean a great deal for the way people experience the relationship between self and surrounding world, including the world of goods" (Jansson, 2013:11).

Although the declared topic of this special issue is the media spectacle of the celebrity brand, the media text par excellence, the underlying current of thought animating discourse is the trope of the media matrix; the mediatrix (Taylor \& Saarinen, 1994): that vast circuit of unbounded relations of identification and dis-identification shaped by the disembodied, the simulated and the imaginary. That we understand brands not only as media objects, but as cultural intermediaries is to say that the possibility of branding as a mode of relational being (Hewer, Brownlie \& Kerrigan, 2013) reproduces the constitutive order of technologies of image, symbol and self. Those technologies function as disembedding mechanisms that lift social relations, as Giddens (1991) remarks, "out of local contexts and rearticulate[s] them across indefinite tracts of timespace" (ibid, 18). The metaphor of disembedding and its recursive articulation as fluid identity speaks of the transformative power of a branding mode of relational being, evident in the new convergent forms of commodified interactivity available via personal mediation devices. Indeed it is possible to argue that in distributing processes of mediation, contemporary smartphones are but early examples of mediation technologies to come as telemetry, connectivity, and computing continue to converge. At present they offer access to image-based modes of individuation where virtual objects such as 
the 'selfie' represent non-personal forms of being which transcend subject and location, reproducing a gaze which is cinematic in its sweep and intensity, a more critical consciousness of meaning systems and forms of assemblage known as 'reflexive accumulation' (Lash \& Urry, 1994).

This special issue investigates these topics as they relate to celebrity in general and the celebrity brand in particular. It unpacks identity theoretics having origins in the turn to celebrity culture and mass-mediated practices of spectacle and glamour. We nudge marketing treatments beyond a staple repertoire rendering celebrity as a field of commercial endorsement opportunities, co-branding positions generated by 'placing' product in appropriate media contexts (Agrawal and Kamakura, 1995; Erdogan, 1999; Keller, 2008): the 'beyond' here refers to the unnoticed work of translation whereby already mediatised cultural fields are remediatised via the interplay of text, image and convention. We theorize the figure of the celebrity as a component of the machinery of identity consumerism which fashions social relations and cultural production as market practice. We argue that celebrities and brands under their cultivation function as organizing devices at the level of everyday interactivity, locating consumer and commodity within networks of affiliation and belonging. In this way we suggest that identity practices of consumer capitalism are shaped and reproduced through mediatized cultures of celebrity; and that our current celebrity culture merely hints at new forms of individuation to come which draw on an emerging metacinematic consciousness where, 
as Deleuze (1989) argues, in the play of exchange and translation, images construct and deconstruct themselves, and the virtual and the actual coalesce.

\section{The Papers}

And so to the papers that make up this special issue: Hackley and Hackley take seriously the cultural production of celebrity in an age of media convergence. Through a persuasive review the authors urge us to move beyond the usual marketing subjects of linearity, meaning-transfer, fit and alignment. The social mediascape, instead, suggests that the "business of celebrity has assumed a cultural intensity, cyclical rapidity, and economic imperative never seen before." (this volume). A world in which, as Jenkins (2008) suggested mediatisation, instant inter-connectedness and the emotional resonance of media brands will come to the fore. An affective economy in which celebrity assumes new significance, for the power it has to reshape markets and the practices of marketing in its own image, or as they suggest: "The performance of celebrity has become part of the daily practice of millions of consumers who upload images, videos, comment and 'statuses' to social media and receive approval ratings in the form of views or 'likes', and, hence the idiom of celebrity as a media performance has become deeply inculcated in consumer culture." (this volume). Celebrity culture, as 
we like to think, offers up new scripts and recipes for participation, new practices to ingest and digest so that all areas of marketing, from branding to retailing, from advertising to promotion, and from PR to strategy cannot now disregard the import of celebrity for its ability to enliven the everyday.

Thompson, Stringfellow, Maclean, MacLaren and O'Gorman also take up the challenge of unpacking celebritisation as the production of culture. Using field theory they reveal the genre of structured reality television for its associated practices, technologies and performances. In this manner, marketplace interactions are constantly in need of new marketplace forms and marketplace actors as carriers of shifting notions of taste and status. From this paper we glimpse the machinery of celebrity branding as technoinfused but also culturally embedded. It was Rojek (2001) who suggested that the cult of distraction is alive and kicking in celebrity culture: "Society requires distraction so as to deflect consciousness from both the fact of structured inequality and the meaninglessness of existence following the death of God. Religion provides a solution to the problem of structured inequality in this life by promising eternal salvation to true believers. With the death of God, and the decline of the Church, the sacramental props in the quest for salvation have been undermined. Celebrity and spectacle fill the vacuum." (2001: 90). Such a reading reveals the anthro-religious roots of celebrity culture but also that media interests feed off and fill the void. The chase for audience 
ratings and participation is well served by celebrity culture, especially when we take into account how issues of identity, gender and class are performed and enacted. Herein tournaments of value as the authors reveal centre upon conflict and its resolution, the striving for economic success and capital. Such spectacles enchant, enhance and entrance with speed and sophisticated ease. In this manner the marriage of celebrity, television and social media is one made in heaven; a fairytale romance of pomp and circumstance with all the crucial ingredients of "love, friendship, sex, debauchery, and infidelity, all leveraged in the creation of celebrity forms" (Thompson et al, this volume).

Reality celebrities in this manner are adroit and savvy marketplace players, actors with a keen sense of the roles they are playing, ever keen to turn a drama into a crisis or two, that is an opportunity to stand out in the marketplace for sentiment and emotion. Here celebrity reveals itself as people feeling emotions together in accord and discord, with a little help from TV magic and the touchablity, proximity and mirroring of such stars to own lives. Glamour may appear as a dish best served alone or in the company of some significant other, but the defining qualities of celebrity are its possibilities for transformation and its shareability, we all participate, we're all complicit. The system demands that of us, how else would it function and maintain itself so efficiently, so 
effortlessly without a little bit of imagining and dreaming of our own as grist for the mill and marketplace of celebrity production.

Mythmaking is thus central to understanding the role of the celebrity in contemporary society, and numerous myths are at play in the celebrity marketplace. Cocker, Bannister and Piacentini look at the relevance of mythmaking in young consumers' identity work. Their selection of two working class celebrities allows them to consider the construction of the celebrity brand which embraces multiple, sometimes contradictory identities. While many papers in this special issue focus on the creation and deployment of the celebrity brand, Cocker et al. examine consumer interpretation and deployment of the celebrity brand as part of their self-construction and acts of sense making. This paper highlights the complex nature of celebrity capital, alongside considerations of social, cultural and economic capital. Interrogating the deployment of the 'celebrity chav' label in relation to British working class celebrities; Jordan and Cheryl Cole (now Cheryl Fernandez-Versini), Cocker et al. illustrate the importance of understanding gender and class in the realm of the celebrity brand. While glamour and allure have been identified as central to the construction of the celebrity brand (see also Stevens et al., this volume), this paper shows the flip side; vulgarity, repulsion and ordinariness which comes into play in media portrayals and consumers sensemaking around celebrity brands. 
Lim and Moufahim turn our attention to the celebrity in the realm of charity. In their exploration of the extreme nature of celebrity suffering displayed in the service of major UK based charities such as Children In Need, Lim and Moufahim found that consideration of such spectacular celebrity suffering poses questions about how emotion has been marketised. Drawing on Guy Debord's work on spectacle, they argue that the deployment of celebrity humanitarianism can result in banalizing the charitable causes at the heart of their activities. Just as Cocker et al. drew on myth making in their study, Lim and Moufahim turn to the heroic myth in understanding the media portrayal of such celebrity humanitarians. The exceptional suffering of these celebrities in pursuit of their charitable goals can overshadow the day to day suffering of the community at the heart of the charitable appeal. While Lim and Moufahim continue the work of other authors who have considered the politics of compassion through the lens of celebrity involvement with charitable causes, their focus on the body, and physical philanthropy, within this realm provides further insight into consumption and the commodified celebrity.

Celebrity may appear fleeting, caught in the moment and emergent but the celebrity lifecycle is played out over time. Taking David Bowie and the market as their starting point, Lindridge and Eagar use structuration theory to explore the careering character of the human brand over time. To the question of who constructs celebrity, the authors 
reveal the importance of a range of agents, from his relationships with his fans to the media agents and the shifting cultural and macro forces that the range of Bowie personas responded to. As a case study in celebrity brand management the paper ends with the suggestion that human brands are best considered from a portfolio perspective to address the challenges of fame and the challenges of aging. Celebrity brands in this regard become caught up in the forces of nostalgia and our own desire for an imagined past lost to time, stuck in cultural moments of resonance which only serve to produce tensions for those looking to escape the bonds of time, history and media/fan fabrication and attachment. But celebrity brands endure especially when the combine a cocktail of musical animation with storytelling artistry. But still the danger of ossification remains, that is the dangers of shifting from marketplace resonance to irrelevance. Celebrity brands are in this regard best understand as fables of transformation, from emancipation to resurrection: from Ziggy Stardust to Heathen, from The Man who could have sold the world to redemption and tales of survival: Let's Dance.

Bowie's allure has much to do with glamour, performance and embodiment, or as we knew it in the early days, Glam Rock. A lesson we learn from Stevens, Cappellini and Smith where the focus is on the Domestic Goddess of fame and kitchen re-enchantment, Nigellissima. The language of transformation and promise remains embedded in the practices of glamour for as the authors reveal the etymology of glamour is otherworldly, 
alchemic, the land of sparkle and magic, enchantment and spells for transformation and success. So that for celebrity brand managers looking for a recipe of vital ingredients for media presence glamour has to be at the top of that list (see also Hewer, Brownlie \& Kerrigan 2013). The problem being that glamour is elusive and illusive, it cannot be simply merely manufactured from base materials rather glamour is visual and kinetic. It is the stuff of myth and marketing, the stuff of femininity and masculinity; a heady blend of camp, class affectation and the sophisticated allure of grace. In this regard, Nigellissima is prime territory for fables of transformation, but something remains, from Nigella Bites to court case spectacle and overexposure something enduring remains in the quest for iconic appeal. Stevens, Cappellini and Smith suggest that celebrity and glamour are not kindred spirts, citing Wilson for whom: 'glamour is untouchable, celebrity touchable'; this may appear the case, one of the ruses of glamour but both reside in the territory of myth and fantasy, prime practices of othering for choreographers of celebritisation to lay claim to.

Another such practice is that of scandal. For celebrity brands as we learn from Quinn, Mills and Patterson's paper are crafted, captured and commodified. Here the focus is on celebrity scandal to question the assumed wisdom that scandal is bad for the celebrity brand. Taking the case of British comedian Russell Brand, Quinn, Mills and Patterson trace the various scandals of Brand the Brand and in so doing, develop the 3Cs of his 
brand narrative. Brand brand is that of the rehabilitated drug addict, who courts controversy and latterly he has turned his celebrity gaze onto what Kapoor 2013 terms 'celebrity humanitarianism'. Indeed both Lim and Mouhfahim and Quinn's papers remind us that engagement with humanitarian work and politics can be a powerful tool in the celebrity kit, which can humanise the celebrity and counterbalance other elements of the celebrity lifestyle which make them difficult to relate to. If celebrities 'are the dream' (Baudrillard, 1988) then it seems that we need the dream to be multifaceted and to sometimes manufacture a myth of caring and compassion to displace the calculations at work. Throughout the paper, Quinn et al. remind us that what makes Brand relatable, is the authenticity of his story, his humble beginnings, his struggle with addiction and his engagement with charity work that directly relates to his life story.

Preece also looks to authenticity to explain the construction, communication and management of the artist-activist brand of Chinese artist, Ai Weiwei. Preece urges us to think of the celebrity brand like we would a corporate brand, one that is constructed and managed. Just as Lim and Moufahim and Quinn do, Preece confirms the place of the celebrity in drawing our attention to specific causes through their ability to intensify public engagement and provoke empathetic response. While Lim and Moufahim's celebrities push themselves outside their usual comfort zones in the service of charity (or perhaps humanising their celebrity brands), and Quinn illustrates the power of the 
celebrity to deploy their celebrity capital in broader spheres of public life, Preece reminds us that celebrity artists political engagement and focus on awareness raising can be deeply entrenched in their core work. So, for the celebrity activist-artist such as Ai Weiwei, their celebrity capital and political actions are bound up one with the other. Indeed, the political/ artistic/ celebrity triumvirate at play in the biography of $\mathrm{Ai}$ illustrate the complex nature of the celebrity brand. Preece draws on corporate branding literature to explore how ideals and values play out in the realm of the celebrity brand.

The concept of authenticity and the celebrity artist is also considered in the paper by Fillis. In his examination of Thomas Kincade, Fillis draws on entrepreneurial marketing to unpack the construction and deployment of authenticity, nostalgia, aesthetics and kitsch in relation to the commodified celebrity. Fillis' paper contrasts nicely with Preece's account of the celebrity artist, reminding us that authenticity is not a static theoretical construct and can be created and understood in many different ways, specifically in relation to celebrity. Kincade's skill in commercially exploiting his work through mass produced products bearing his artwork is a reminder that the celebrity artist does not need to reside at the level of high culture or be driven by wider political considerations. Art as business and the role of the well-known and celebrated is clearly illustrated through Fillis' analysis of how the celebrity artist, with clear commercial ambitions engages in market making and shaping. 
Davies and Slater urge us to unpack celebrity brands through a focus on unpaid market communications. In this manner the vibrancy, spontaneity and currency of celebrity practices is often expressed in terms of new media: tweets, blogs and online reports. Using a case study method and questionnaire the authors focus upon two male sportspeople, Andy Murray and Lewis Hamilton, to reveal how celebrity appeal is not only a product of personality variables, but also the shifting character of media reportage. In this regard, media hype and the value of unpaid communications cannot be underestimated when calculating the value of a celebrity's appeal. More so performance, in the form of success (winning) but also emotional resonance (in the form of Murray's 'tears') should not be underestimated when trying to unpack the forms of appeal and connectivity they make possible. But also social media platforms are where such appeals get fought over and wrestled into shape. In this manner, celebrity reveals itself through its technologies of affect and brings in its wake the social as reassembled and redistributed for marketplace success.

Lunardo, Gergaut and Livat set themselves the task of answering the question of what makes a celebrity appealing. Using a quantitative dataset gathered from the US context on the popularity and perceptions of more than 3,000 celebrities they are able to reveal the positive effects of a range of personality factors such as sophistication, sincerity, competence and excitement. For celebrity brands and their brand managers such 
information could be a useful starting point in the quest for 'image capital' and standing out in this cluttered marketplace. As they suggest all such factors can be enhanced and worked upon through strategies for celebrity ambition. Through training, diet, and surgery the authors suggest celebrities might improve their attractiveness and through charity work perhaps levels of sincerity might be enhanced (see also Lim, this volume). The labours to manufacture appeal are never-ending as the authors also suggest that for the majority of celebrities time is not a great friend (a lesson we learned from Lindridge and Eagar, in this volume), especially for sportspeople and TV stars with most having to face the fact that their appeal and charms will dwindle so that efforts to maintain their appeal will become more dramatic and calculated.

\section{Conclusion}

For those of us interested in social life, how it is organized and structured, its responsibilities and problematics, its securities and forms of reassurance the papers in this volume suggest that a useful starting point must be celebrity culture. In the marketplace for sentiment and emotion celebrities do well, the emotional economy is fuelled and engineered through our desire for something else. For celebrity culture is perhaps the fullest expression we have of our hopes and dreams as imagined made 
material and given human form. The papers in this special issue chime well with this suggestion, furthering our understanding by taking up the invitation and challenge to think celebrity and the import of celebrity culture in contemporary society. Add some sparkle is the constant refrain of celebrity culture, and being immune to its charms and reveries is no simple task. In this regard, celebrity culture is where the action is, where the social gets assembled and reassembled, performed and better distributed. Celebrity overflows with possibility. Celebrity overflows with value, which is simply another way of suggesting that celebrities possess forms of cultural power through the networks and authority they wield; or even that celebrity culture is the logic of late capitalism at work (as Jameson (1991) might have said), or as we prefer celebrity capital-ism. How else could we explain the media, economic and cultural imperatives at work? And in troubled times, when the bitter pill of constant Bad News is hard to swallow, it is easy to see how celebrity as ritualised performance and transformation weaves its magic spell of sparkle and light.

\section{A final thanks}


We thank the authors who took up our invitation and the reviewers who committed their labours to the task of constructing this special issue. Special thanks also go to Fiona Lees and Anne Foy, the Westburn team who kept us on track.

\section{References}

Agraval, J. and Kamakura, W.A. (1995). The Economic Worth of Celebrity Endorsers: An Event Study Analysis. Journal of Marketing, Vol.59, 3, pp.56-62.

Arvidsson, A. (2006). Brands: Meaning and Value in Media Culture. London: Routledge.

Baudrillard, J. (1988). Selected Writings. Oxford: Polity Press.

Baudrillard, J. (1998). The consumer society: Myths and structures. London: Sage.

Bourdieu, P. (1984). Distinction: A social critique of the judgment of taste. Cambridge, MA: Harvard and Routledge \& Keegan Paul.

Castells, M. (2001). The Internet Galaxy. Oxford: Oxford University Press.

Deleuze, G. (1989). Cinema 1: The Movement-Image. London: The Athlone Press.

Douglas, M. and Isherwood, B. (1980). The world of goods: Towards an anthropology of consumption. London: Penguin.

Erdogan, Z.B. (1999). Celebrity endorsement: a literature review. Journal of Marketing Management, Vol.15, 4, pp.291-314. 
Giddens, Anthony (1991) Modernity and Self-Identity: Self and Society in the Late Modern Age. Cambridge: Polity Press.

Hewer, P., Brownlie, D. and Kerrigan, F. (2013). The exploding plastic inevitable' : 'Branding being', brand Warhol and the factory years, Scandinavian Journal of Management Vol.29, 2, pp.184-193.

Jameson, F. (1991). Postmodernism, or, the cultural logic of late capitalism. London: Verso.

Jansson, A. (2013). Mediatization and Social Space: Reconstructing Mediatization for the Transmedia Age, Communication Theory, Vol.23, pp.279-296.

Jenkins, H. (2008). Convergence Culture: Where Old and New Media Collide. New York: New York University Press.

Keller, K. (2008) Strategic Brand Management, London: Financial Times/Prentice Hall. Lash, S. \& Urry, John (1994). Economies of Signs and Spaces. London: Sage.

Lury, C. (2004). Brands: The Logos of the Global Economy. London: Routledge.

Rojek (2001). Celebrity. London: Reaktion books.

Taylor, M.C. and Saarinen, E. (1994). Imagologies: Media Philosophy. London: Routledge. 
Turkle, S. (1997) Life on Screen: Identity in the Age of the Internet. New York, Touchstone.

Wolfe, T. (1988). Bonfire of the Vanities. New York: Cape. 